\title{
The Central-Local Relationship and Constitutional Operations in France
}

\author{
Chun-Hao Chang \\ Department of Political Science, Tunghai University, Taichung, Taiwan
}

Email address:

chunhao@thu.edu.tw

\section{To cite this article:}

Chun-Hao Chang. The Central-Local Relationship and Constitutional Operations in France. Humanities and Social Sciences.

Vol. 4, No. 2, 2016, pp. 16-25. doi: 10.11648/j.hss.20160402.11

Received: February 24, 2016; Accepted: March 2, 2016; Published: March 12, 2016

\begin{abstract}
This paper argues that the French model of Semi-presidentialism shows two features. One the one hand, the President is the head of both the central government and local affairs due to France's historical background as a highly centralized state. On the other hand, the political struggle between the local executive heads and the central government influences not only the Executive power, but also the Executive-Legislative interaction from the bottom. Moreover, the Constitutional Amendment in 2008, in which the Presidential and the Parliamentary powers were reinforced, makes the central-local relationship a key to estimating the future development of the Constitutionalism in France.
\end{abstract}

Keywords: Semi-presidentialism, France, Paris, Central-Local Relationship

\section{Introduction}

The operation of France's constitutional system has long been a matter of considerable interest. Beginning with the implementation of the 1958 Constitution of the Fifth Republic, and the first appearance of the term "semi-presidential system" in Le Monde in 1959, followed by French scholar Maurice Duverger's (1970, p. 277) formal definition of the term, the Constitution of the French Fifth Republic has become an important focus of academic research. Although French scholars continue to hold divergent views on the definition of the constitutional system, due to the fact that semi-presidentialism is an innovative constitutional type, and a growing number of emerging democracies have followed the Constitution of the French Fifth Republic and adopted a system of government distinctive from presidential or parliamentary designs, French-style semi-presidential government now occupies an important place in the field of comparative politics (Grossman \& Sauger, 2009, p. 243), and is typically regarded as an archetype for the semi-presidential system.

Furthermore, As Robert Elgie has pointed out, in recent years, the emergence of research on governance into the mainstream has made dependent variables such as economic issues, economic growth, cabinet stability, and human rights protection key areas of attention in research on the governance capacities of semi-presidential systems, in turn producing a greater diversity of independent variables, shifting the focus of research (Elige, 2004, p. 320). In fact, the increasingly diverse layers of governance mean that the government has to deal with highly complex governance issues. Therefore, as a democratic constitutional type, if the focus of semi-presidentialism is placed at the national central government level in an attempt to understand the triangular relationship between president, premier, and parliament, it may be difficult to understand the actual constitutional functioning of semi-presidential systems, and may make it impossible to assess democratic quality. Therefore, this paper starts from the fusion of "central-local government relations" and semi-presidentialism to identify important new variables in the study of semi-presidentialism. This study argues that assuming the governance process involves both central and local levels, if research on semi-presidentialism is able to incorporate local government and its effect on the operation of central government institutions, or the effect of central government on the logic of governance at the local level, this will provide us with a new understanding of the key focus of research on semi-presidentialism -the triangular relationship between president, premier, and parliament. In particular, in research on semi-presidential systems, the focus on "horizontal 
division of power" has meant that the role of local authorities and the effect of "vertical division of power" on the functioning of semi-presidential systems have been mostly ignored. Therefore, this study attempts to combine research on central-local government relations and semi-presidential systems, in the hope that it will enrich research on semi-presidentialism.

This paper argues that as a unitary state, in France's recent processes of decentralization and deconcentration, the influence of France's historic centralization on the central government's delegation of power to local authorities or the influence local authorities can exert on the operation of the central government through their self-governing powers are issues that cannot be ignored when examining the functioning of France's constitutional system. Therefore, this study begins from this historical context by examining central-local government relations in the context of the historical evolution of France's centralized system as a means to identify the position of the central government in the governance process. Second, with regard to the institutional functioning of central-local government relations, this study begins with dominant executive power, before developing the analysis in the functioning of executive power and local politics - the interaction between the president and local authorities in the municipal policy analyzing the links between the central and local authorities in the governance process, and exploring how powers are exercised. This study uses France's main city, Paris, as the source of data analysis. Historically, Paris is the only French city with the legal status of both commune and department (département), meaning that the mayor and Council of Paris simultaneously possess the powers of the two levels of government. The development of high levels of municipal autonomy and influence, and the linkages between the municipal leader, councilors, and the central government, help us to understand the logic of how semi-presidential systems operate in the interactions between central and local government.

\section{The Historical Development of Central-Local Government Relations in France}

\subsection{The Institutional Foundation of Central-Local Government Relations}

By the Fifth Republic, France had been through two empires, the Vichy regime, and five republics, and sixteen constitutions. France's history of royal autocracy shaped the institutional framework of the centralized state. The centralization of the Napoleonic period based on the concept of a "single administration" was incorporated into the politics of the country; at the same time a historically strong military ideology further strengthened the central government in its implementation of executive orders. However, under France's political tradition of a strong state, the establishment of local institutions was also profoundly affected. France's local authorities: region, department, and commune, are all viewed as products of this history.

Although the French Revolution was a political watershed, France's long-term centralization has meant that after the emergence of republican France, while the democratic republic established the basis for the legitimacy of decentralization, there was still strong suspicion of deconcentration in the National Constituent Assembly, affecting the formation of institutions for central-local government relations in the current French constitution. A review of the literature shows that the writers of the constitution not only decided to strengthen the center, reducing the chance that it could be challenged (Liu, 2007, p.74), local administrative units were also reorganized, establishing the lowest level of local administration as the "commune" on the basis of the parishes ("paroisse") that had been established beginning in the Middle Ages, also dividing France's historic provinces into 83 departments. Under the spirit of a national unified territory (Wollmann, 2004, p. 655), this formed the basis for the internal organization of the central administrative system (Weng, 2013). According to the thinking of the time, communes had a dual nature. The communes both exercised executive power on behalf of the central government and governed the area under their control as a representative of the people. This basic unit of local administration was headed by a mayor (maire) assisted by a municipal council (conseil municipal) who supported the powers of the former. The current mechanisms governing the interaction between mayor and municipal council within local authorities is still based on the logic of "strong administrative leadership," with the mayors still possessing a dual role as both the representatives of the central government and the representatives of the residents of the commune. In 1800 , on the condition that the departments were retained, the Premier Consul Napoleon Bonaparte introduced a new system of prefects (préfet) directly appointed by the Premier Consul (meaning the Emperor under the Imperial system). For each of the arrondissements within the departments, a sub-prefect (sous-préfet) was established, with mayors at the commune level, all appointed by the central government. Even today, the prefect and sub-prefect remain centrally appointed (Weng, 2013).

France's institutional legacy of central-local government relations shows that the self-governing powers of local authorities did not alter as a result of regime change. This trend did not start to change until the first Parti Socialiste government in the Fifth Republic. Under the leadership of François Mitterrand, the "Loi 82-213 du 02 Mars 1982 Relative aux Droits et Libertés des Communes, des Départements et des Régions" (normally referred to as the Law of Decentralization) passed in March 1982 is generally regarded as the basis for French decentralization, as well as the beginning of decentralization in practice (Weng, 2013). This institutional reform, which devolved important political and administrative responsibilities from central 
government agencies to the local level, was an inevitable response to the modernization of France's political system and challenges brought about by changes in the international political and economic environment (Wollmann, 2000, p. 42). Therefore, the question of whether this system can move beyond the historically embedded role of the state has been a long-term issue of concern.

On the basis of the discourse of strengthening decentralization in order to create local identity, the most significant innovation in the Law of Decentralization was to create the legal status of the "region" on the basis of France's historical provinces, ${ }^{1}$ establishing the current three level institutional framework for local authorities. Under this system, powers were decentralized to the regions, departments, and communes according to function (Smith $\&$ Heywood, 2000, p. 10). From a functional point of view, the regions took responsibility for promoting economic development and regional distribution, while the departments focused on social assistance and protection policy, and the communes were responsible for the provision of basic public goods and services. The local organizational framework produced by this reform is shown below:

Table 1. The Law of Decentralization and Division of Powers between Local Authorities.

\begin{tabular}{ll}
\hline & Regional development \\
& Economic development \\
Region & Environment (nature parks within the region) \\
& Education (lycée) \\
& Training \\
& Tourism \\
& Social care \\
& Urban development (urban infrastructure and local \\
& development) \\
& Education (collège) \\
Environment & Tourism \\
Cultural activities \\
Social care \\
Education (école primaire or health) \\
Urban planning \\
\hline
\end{tabular}

Source: Smith \& Heywood (2000, p. 10)

From the above distribution of powers, there is no clear top-down hierarchy between local authorities in France, but rather a form of multi-level governance (Smith \& Heywood, 2000, p. 10). Although the region, department, and commune are seen as three levels of local authority, their powers are not entirely separate. For example, it is difficult to distinguish between "regional development" and "urban development," meaning that the performance of governance

1 Since 1956, France divided 22 administrative regions as bodies to implement state planning, which differentiated from formally defined later. functions often depends on the actions of local authorities at other levels. This situation is particular clear at the level of the region. Regions were planned by the state and are directly linked to the central government, with their budgetary allocation typically established after negotiations with the central government. When compared to the other two local authorities, the regions also have the lowest share of the budget. As shown in the table above, although the regions are able to establish and develop policy, this policy can only be effective through the actions of the departments and communes. Therefore, as a result of their position in French local administration, the governance capacities of the regions are still considered weak (Smith \& Heywood, 2000, p. 17).

Both the mayor of the commune and the departmental prefect appointed by the central government reflect the institutional framework of the centralized state. As mentioned previously, the influence of Napoleon's concept of a "single administration" established a relationship of subordination between local leaders as part of the centralization of power. Therefore, when local autonomy was introduced, powers over the commune remained in the hands of the mayor, who retained executive power over the commune, with the council not authorized to discharge the mayor from his or her duties. In addition, the prefect is traditionally the state's representative in a department, and also acts as the regional prefect where the regional government is located. This system not only remains in place, the power delegated by the central government to the prefect ensures that he or she is able to exercise oversight over the local authorities (Weng, 2013: pp. 38-39). Therefore, commentators also believe that under the framework of local autonomy established by the "Law of Decentralization," although central government prior supervision over local authorities has been abolished and local autonomy implemented, local authorities are still subject to various forms of supervision. Prefects, still centrally appointed under the new law, are used to strengthen post supervision in their role as the state's representative responsible for judicial oversight (Chen, 2004, p. 46).

\subsection{The Institutional Functioning of Central-Local Government Relation}

In summary, the development of France's centralized system and the evolution of deconcentration are closely intertwined processes. This institutional legacy helps us understand why the focus of French decentralization was centered on the delegation of powers, reassigning responsibilities for the provision of public services. Furthermore, following decentralization, the overlap between the three levels of local authority in France resulting from a functional division of powers, and the fact that powers are delegated to centrally-appointed prefects and mayors who also partially represent the central government, mean that there are still many opportunities for the central government to become involved in local politics. 


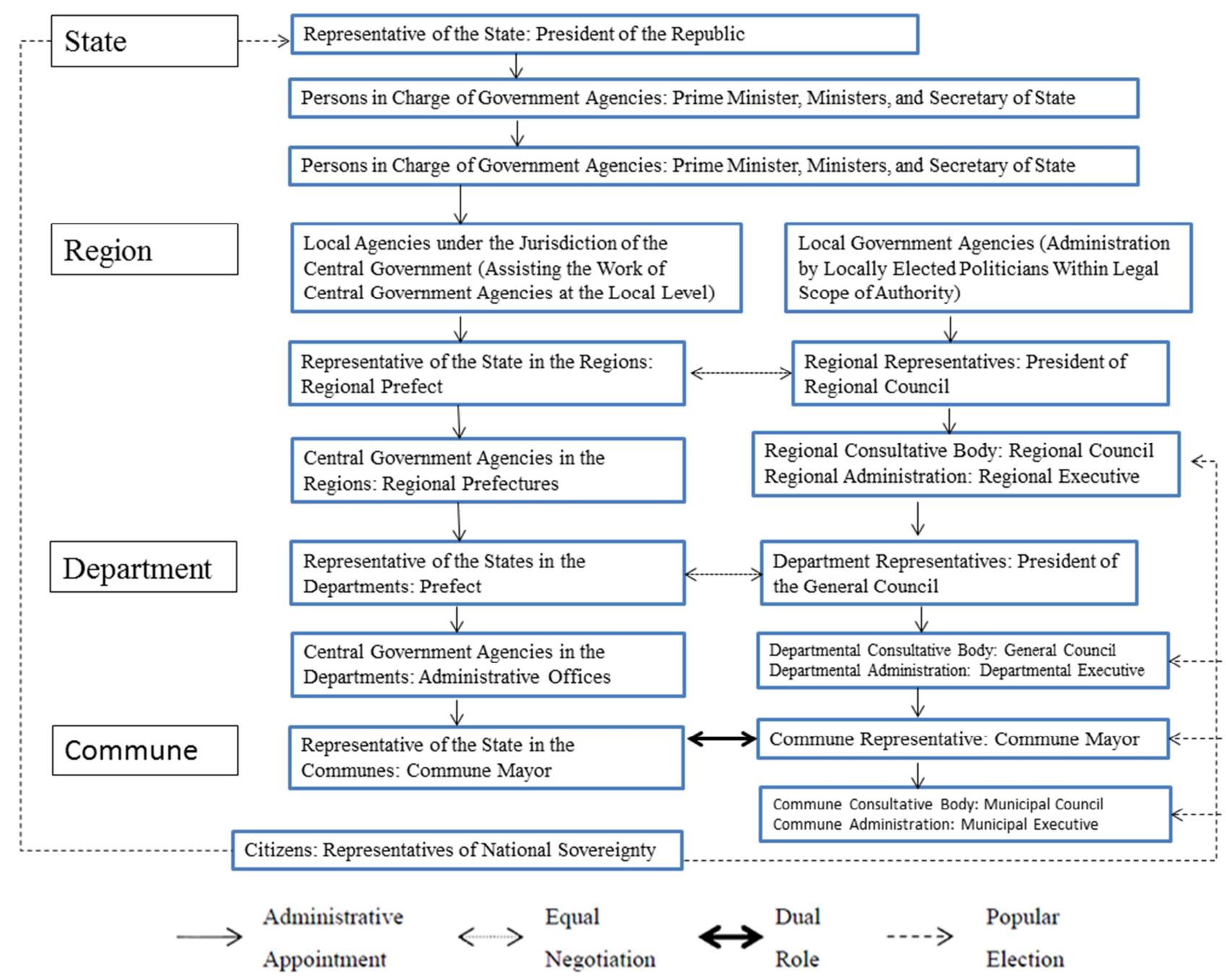

Source: adapted from Zhao (2007)

Figure 1. France's Central-Local Government Relations and Governance Framework.

In 2003, constitutional amendments provided the basis for new laws to implement the new constitutional rules, completing the "regionalization" of France's local authorities and marking a new phrase in the development of France's local government institutions. ${ }^{2}$ This represented a more meaningful reform towards deconcentration, earning the title of the second deconcentration movement. The 2003 constitutional reforms changed how France defines itself. It recognized the principles of decentralization and for the first time provided constitutional protections. Aside from establishing the regions in the constitution, making them constitutionally valid, the autonomous status of local

2 The Constitution of the Fifth Republic was amended in August 2003. Article 72 indicates the legal status of the territorial communities: "The territorial communities of the Republic shall be the Communes, the Departments, the Regions, the Special-Status communities and the Overseas Territorial communities to which article 74 applies. Any other territorial community created, if need be, to replace one or more communities provided for by this paragraph shall be created by statute. Territorial communities may take decisions in all matters arising under powers that can best be exercised at their level." authorities was also established. During this process, the expansion of the powers of the regions and local democratization formally marked the regions as a new level of local government enjoying the same levels of autonomy as other local authorities. However, since the regions must coexist with other mechanisms, under this system deconcentration is unable to escape the previous multilevel operation that was established under the centralized state. ${ }^{3}$ Under Article 72 of the new constitution, regions, departments, communes, and federations of communes

3 Article 72 of the Constitution of the Fifth Republic also provides: "In the conditions provided for by statute, these communities shall be self-governing through elected councils and shall have power to make regulations for matters coming within their jurisdiction.", "In the manner provided for by an Institutional Act, except where the essential conditions for the exercise of public freedoms or of a right guaranteed by the Constitution are affected, territorial communities or associations thereof may, where provision is made by statute or regulation, as the case may be, derogate on an experimental basis for limited purposes and duration from provisions laid down by statute or regulation governing the exercise of their powers." 
(communauté de communes) are all competing to take over responsibilities previously belonging to the central government or other public bodies. This brings the reform in the direction of a vertical division of powers, reflected in both centralized and decentralized institutional design meaning that local authorities in France are not faced with a single subordinate relationship, but have more scope for negotiation and consultation on an equal basis.(Weng, 2013) This institutional architecture is shown in the Figure 1.

From the perspective of the historical developments outlined above, the two waves of decentralization in 1982 and 2003 represented a dialogue with and challenge to the traditional autocratic state. Therefore, in a situation where legacies of the traditional system still remain, and administrative centralization and deconcentration coexist, how will this affect the evolution of deconcentration reforms in France? I believe this is a subject that will be of interest to many researchers. However, before making forecasts about the future, this study argues that the effect of France's central-local government relations on the central government, the role of executive and legislative power as well as the operation of the semi-presidential system should also be regarded as important issues in the development of local institutions in France.

\section{Constitutional Functioning and Local Affairs}

\subsection{Centralization and Features of the Constitutional System}

France's centralization is politically based. However, the establishment of local institutions was not only bound up with the consolidation of executive power, but also took place in the context of contemporary local governance. After the founding of the Fifth Republic, President Charles de Gaulle attempted to stabilize executive decision-making mechanisms, establishing political institutions designed to both ensure political stability and strengthen executive power, making a strong executive the defining feature of the Fifth Republic. Therefore, when discussing French semi-presidentialism, commentators often highlight its "presidentialization" (Elgie \& Moestrup, 2007, Hao, 2013).

In September 1958, the constitution of the Fifth Republic was passed in a referendum. In order to avoid a repeat of the frequent issuing of no-confidence votes and weak government authority in the Third and Fourth Republics, the constitution established a "strong executive, weak legislature." In addition, the October 1962 revision to the constitution that introduced direct presidential elections (Article 6 of the Constitution) further strengthened the legitimacy of the president, thereby establishing the institutional features of France's semi-presidential system. Duverger used France's constitutional system as the main blueprint to establish his definition of semi-presidentialism, meaning that France is often considered an "archetype" for semi-presidentialism. Following his return to power and establishing the new constitution, De Gaulle repeatedly stressed that the president's powers and popular legitimacy must be strengthened. For example, in a news conference in January 1964, De Gaulle not only argued that France was not suitable for a British parliamentary system; it was also not suited to an American presidential system. He also clearly outlined the "relationship of authority" between president and prime minister. Possessing significant constitutional powers and enjoying significant constitutional legitimacy due to the need for two rounds of voting, the constitutional position of the president in the Fifth Republic has had a profound impact on other constitutional bodies. ${ }^{4}$

In 2000, France amended its constitution to reduce the presidential term from seven to five years, with the aim of reducing the occurrence of cohabitation caused by different coalitions controlling the presidency and parliament, thereby ensuring that the president had a "quasi-automatic parliamentary majority." In addition, the sweeping constitutional changes in 2008 originated with widespread calls for a "Sixth Republic," and a widespread belief that the indivisibility of presidential leadership should be made explicit. A majority of French scholars also believe that the constitutional amendments introduced between 2000 and 2008 produced a "presidentialization of the regime (Hao, 2010)." In addition, the low support for the parliament over the past decade has allowed the government the ability to control the parliamentary agenda more directly (Costa, Lefébure, Rozenbergm, Schnatterer, \& Kerrouche, 2012, p. 301). This increasingly apparent situation coupled with the fact that a majority of members of parliament also serve as local councilors or in local administrative posts, mean that the vast majority of parliamentarians have focused their energies back on constituency affairs. This has produced data showing that each member of parliament spends only 2.5 days a week in Paris dealing with parliamentary affairs, with the remaining time invested in constituency matters (Costa, 2013a, p. 283). Beginning with the implementation of the 1958 Constitution of the Fifth Republic, the operation of France's constitution has been characterized by "presidentialization." The president uses public opinion and the operation of political parties to exercise control over executive bodies and parliament, putting both the prime minister and parliament in a comparatively weak position. As a result, most scholars regard the French parliament as a comparatively unimportant institution, meaning that most research is instead concerned with the executive. Even though current president François Hollande and previous president Nicolas Sarkozy have both put forward initiatives to reform the powers of parliament during their terms in office, overall, France's constitutional operation is still based on the subordination of the parliamentary majority, government, and prime minister to the president.

\footnotetext{
4 The regulations of the electoral college faced a challenge soon. In the term of office of President Charles de Gaulle, he supported the amendment to the Constitution after the attack of Petit-Clamart. The parliament no longer exclusively had the name of the people. The direct election of the president sets the stage for the legitimacy of presidential policies. Thus, the president in reality is the leader of the state.
} 
Thus, opponents point out that members of parliament who concurrently hold local offices have low attendance in parliament and parliamentary committees. During his election campaign, incumbent president François Hollande stated his opposition to the dual mandate (Weng, 2013).This electoral promise was passed by the parliament on June 3, 2013 (2000 law). The law stipulates that: "Members of the National Assembly, Senators, and Members of the European Parliament may not hold local executive posts (including mayor, deputy mayor, president or vice president of the general council, or president or vice president of regional councils, or president of communal cooperative organizations), he or she must choose between retaining the central or local office." However, on the one hand, we need to wait until the 2017 legislative elections to begin to understand the actual influence of this reform. On the other hand, as the reform does not prevent members of parliament from concurrently serving as local councilors, some scholars believe that from an institutional perspective of the mixing of local executive and legislative functions, if members of parliament lose their seat, they may return to the municipal government and demand that "the original mayor steps down," possibly making many local offices extremely popular (Rowland, 2013).

Beginning with the implementation of the 1958 Constitution of the Fifth Republic, the operation of France's constitution has been characterized by "presidentialization." The president uses public opinion and the operation of political parties to exercise control over executive bodies and parliament, putting both the prime minister and parliament in a comparatively weak position As a result, most scholars regard the French parliament as a comparatively unimportant institution, meaning that most research is instead concerned with the executive. Even though current president François Hollande and previous president Nicolas Sarkozy have both put forward initiatives to reform the powers of parliament during their terms in office, overall, France's constitutional operation is still based on the subordination of the parliamentary majority, government, and prime minister to the president.

As a result, from the perspective of the central government, executive power is shaped by the dominant position of the president, also defining the role of members of parliament. In addition to the operation of local institutions in France, under the combination of executive power and deconcentration, the question of how executive power affects local governance is an issue worth considering further. In the historical context of power "distribution" in French local politics, how does the interaction between actors including locally elected leaders, centrally appointed prefects, and local councilors, together with the leadership of the central government affect the governance process? This is a key dimension for bringing together constitutional operation and central-local government relations.

\subsection{Dominant Executive Power and Municipal Politics in Paris}

This study uses Paris as its case for analysis. Aside from its position as France's leading city, a more important reason for this choice was the city's special position in local government, which enables us to carry out a comprehensive discussion of central-local government relations. France has no "special municipalities," but for densely populated Paris, Marseille, and Lyon, the 1982 Paris-Marseille-Lyon (PML) Law provided for the internal administrative divisions of these cities. Under this law, Paris became the only city in France to have the legal status of both commune and department, with the powers of the mayor and council covering both the jurisdictions. On the one hand, the political and economic importance of Paris meant that its leaders could often use their influence to resist the rule of the central government. However, on the other hand, even as France's most important city, with an elected mayor and autonomous local powers, France's centralization is still apparent (Kuhlmann, 2007, p. 13-14). In order to avoid the mayor of Paris acquiring too much power, aside from appointing a prefect to supervise the local authority on its behalf, the central government also appoints a Prefect of Police charged with police security for the city of Paris.

Influenced by France's long history of centralization, the institutional design for the city of Paris also follows an administrative tradition of centralized bureaucracy. The mayor leads the municipal government in the fashion of a monarchical leader. Accordingly, as described above, the combination of centralization and local governance produces a dilemma that is particularly evident in the operation of municipal government in Paris. Paris not only has a dual administrative system being both a department and commune, the Council of Paris also simultaneously possesses both of these powers. The mayor of Paris is elected by the councilors, and is simultaneously a member and president of the municipal council, as well as providing legitimacy for the city of Paris municipal government. In addition, the city of Paris contains twenty municipal arrondissements, each with its own council (conseil d'arrondissement) which elects a mayor (maire d'arrondissement). Around one-third of the councilors in the twenty arrondissements are also municipal councilors for the city of Paris. Concerning the actions of the municipal government towards the arrondissements, councilors in the arrondissements can make verbal or written interpellations to the Council of Paris. The arrondissement councils can also make prior representations concerning any plan made by the city of Paris that involves the arrondissement. As for the arrondissement mayor, his or her responsibility is in the implementation of arrondissement council resolutions and carrying out the dual functions of powers devolved from the central government and deconcentration. ${ }^{5}$ To summarize the above, the roles of arrondissement councilors and mayors, city councilors, and the city mayor are closely linked (as shown in Figure 2). During his eighteen year tenure as Paris mayor (1977-1995), Chirac in his dual role as president of the municipal council and leader of the municipal executive

5 Each arrondissement council selects their own president of the arrondissement council, generally the first of the list. In Paris, about one-third of arrondissement councilors of each arrondissement may be a "municipal councilor" at the same time. They are the highest ones of the list calculated by votes and rankings. 
was considered to have the functions of "strong mayor," "municipal presidency," and even "municipal monarchy."

Given the strong linkages between the local executive and legislature, municipal politics in Paris not only has a multi-level governance framework, from a political perspective, overlapping actors mean that actor-interests are a particularly important topic for research. As a major city, Paris is closely linked to the central government, further strengthening the influence of this factor. Scholars have argued that Paris can be described as a site for party competition and power competition. For the president, if his or her rivals or potential successors hold an important position in the city of Paris, political wrangling over central government policies is likely to occur. Therefore, in the process of municipal government, if the president, city government, Council of Paris, and the arrondissement councils are fragmented, this is likely to create difficulties in the urban development process. In addition, the role of the prefect as an intermediary between the central and local government, strengthens the ability of the central government to supervise the municipal government. Generally speaking, as an agent of the central government, the prefect supervises the mayor by exercising legal controls, defends the interests of the state, and has the right to participate in the drafting of municipal laws. This adds to the complexity of the interaction between the central government and local authorities.

In the operation of the centralized state, the intervention of the central government in the development of Paris is based on legal enforcement, shaping competition for political and executive power between the president and the mayor. After Chirac became mayor of Paris in $1977,{ }^{6}$ while he used the slogan "the mayoralty of Paris first," aside from the sitting President Valéry Giscard d'Estaing's constant attempts to dilute the power of the mayor, Giscard d'Estaing's successor the socialist François Mitterrand passed the PML law strengthening the powers of the municipal districts. Chirac himself launched a top-down mobilization of the Paris right-wing to weaken the conservative leadership, as well as strengthening his own powers as mayor. In order to reduce the impact of the PML law and prevent the devolution of powers from the municipal government, Jacques Chirac made co-opting the arrondissements mayors an important strategy. Chirac and his successor Jean Tiberi allowed the arrondissements mayors to take concurrent posts in the municipal government (adjoint au maire de Paris). Under the reciprocal relationship between the city mayor and mayors of the arrondissements, before 1995, the political map of Paris was almost entirely controlled by the right, with the city mayor and mayors of the arrondissements even reaching an agreement to weaken the influence of the PML law. The city mayor led the arrondissements' opposition to the central

6 The city mayor of Paris was appointed by central government after 1871 . Since 1997, the Municipal Council of Paris has had the right to elect the city mayor of Paris in order to stimulate local creativity and motivation. The city mayor is elected for 6 years. From then on, the independence of the city government of Paris against the central government enhanced greatly. government, particularly in the power struggle between Chirac and Mitterrand, indicating that the arrondissements have not become genuinely autonomous units with substantive functions or decision-making ability. Chirac implemented the law to the minimum possible, and rejected the law's principle of decentralization, meaning that Paris continued to develop according to its institutional traditions and administrative culture, reflecting strong path-dependence.

In addition, from the urban planning process in Paris, political competition is even more apparent. The Greater Paris (Grand Paris) initiative passed in July 2010, ${ }^{7}$ showed the leadership of the central government over municipal politics in Paris, as well as conflict between central and local governments. The first article of the Greater Paris Law stipulates: "This is a national economic and social urban plan, producing a large-scale land policy to unify the Île-de-France and promote the development of economic sustainability and social solidarity, as well as generating employment opportunities for the capital region." Therefore, it is clear that as this national level project directly involves land development, it is significantly different from previous urban planning carried out under the local system. The "Greater Paris Metropolis" (la métropole du Grand Paris) plan put forward by former prime minister François Fillon sparked opposition from the arrondissements. According to a survey by Le Journal du Dimanche, regarding the Greater Paris Metropolis project, $52 \%$ of arrondissement mayors (with the population of $80 \%$ of these arrondissements exceeding 10,000 people) stated they were not willing to give up their existing housing and urban planning powers. In addition, as former president Nicolas Sarkozy proposed the "regional rail network plan" and "multipolar development" (referred to as the Grand Huit), that differed from the Arc Express project proposed by the regional council and the metropolitan transportation authority, the Syndicat des transports d'Île-de-France (STIF). This not only aroused the strong dissatisfaction of the local authorities in Paris (Belkind, 2013); incumbent mayor Bertrand Delanoë also expressed his opposition to former president Nicolas Sarkozy's leadership of the Greater Paris project, directly accusing the president of "attempting to capture a lively city that should be the responsibility of local officials".

The "Greater Paris Metropolis" project based on the exercise of state power to control the future of Paris, demonstrates that urban planning has becoming an important way of building public support for politicians and other stakeholders. Even when local actors do not have legally enforceable rights, the competition over development strategies for Paris may also manifest a power struggle

\footnotetext{
7 "Grand Paris" was first proposed on April 2009 when President Sarkozy made an speech at Cité de l'Architecture et du Patrimoine Palais de Chaillot. The plan includes a driverless subway linking Paris and the surrounding communes built in 2012 or 2013, and the transport plan will be carried out in ten years. The purpose of "Grand Paris" is to make Paris a global city where people may have an accessible transportation system, a great quality of life, a high culture and a well-developed economy.
} 
between the state and localities. In the case of the Grand Huit project led by Nicolas Sarkozy, subsequently the central government compromised with the arrondissements, leading to the arrondissement councils and the executive branch compromising on new content for the plan, revealing a process of metropolitan democracy. This is similar to the Rive Gauche plan during Chirac's period as mayor that broke with the centrally imposed height restrictions on buildings. Following François Hollande's election to the presidency, the party turnover resulted in weaker implementation of the Greater Paris plan. However, on October 8, 2013, the French senate finally passed the Greater Paris plan by 156 votes to 147 votes (although the plan has still yet to pass the National Assembly). This demonstrates that municipal politics in Paris is a negotiated network, illustrating the political realities the central government must face when guiding policy.

Based on the above, from the role of the basic level of district government in Paris, tracing back to the interaction between the mayor and the central government, from a perspective of the development of municipal politics in Paris, first of all, centralization and strong executive power in the municipal government lead by the mayor in competition with the president, may lead to a decline in the local institutions. The passage of the PML law and party competition show local autonomy. However, the control of the central government over the local government has also made the district government the subject of political mobilization by the city mayor. The distribution of powers and binary administration created by local institutions and the overlap between executive and legislature has created municipal development based on government by a strong mayor. In addition, the competition between left and right in the national government has also spilled over into Paris municipal planning. The evolution of the "Greater Paris Metropolis" plan in the context of the rise and fall in fortunes of political parties at the national and local level is evidence of this.

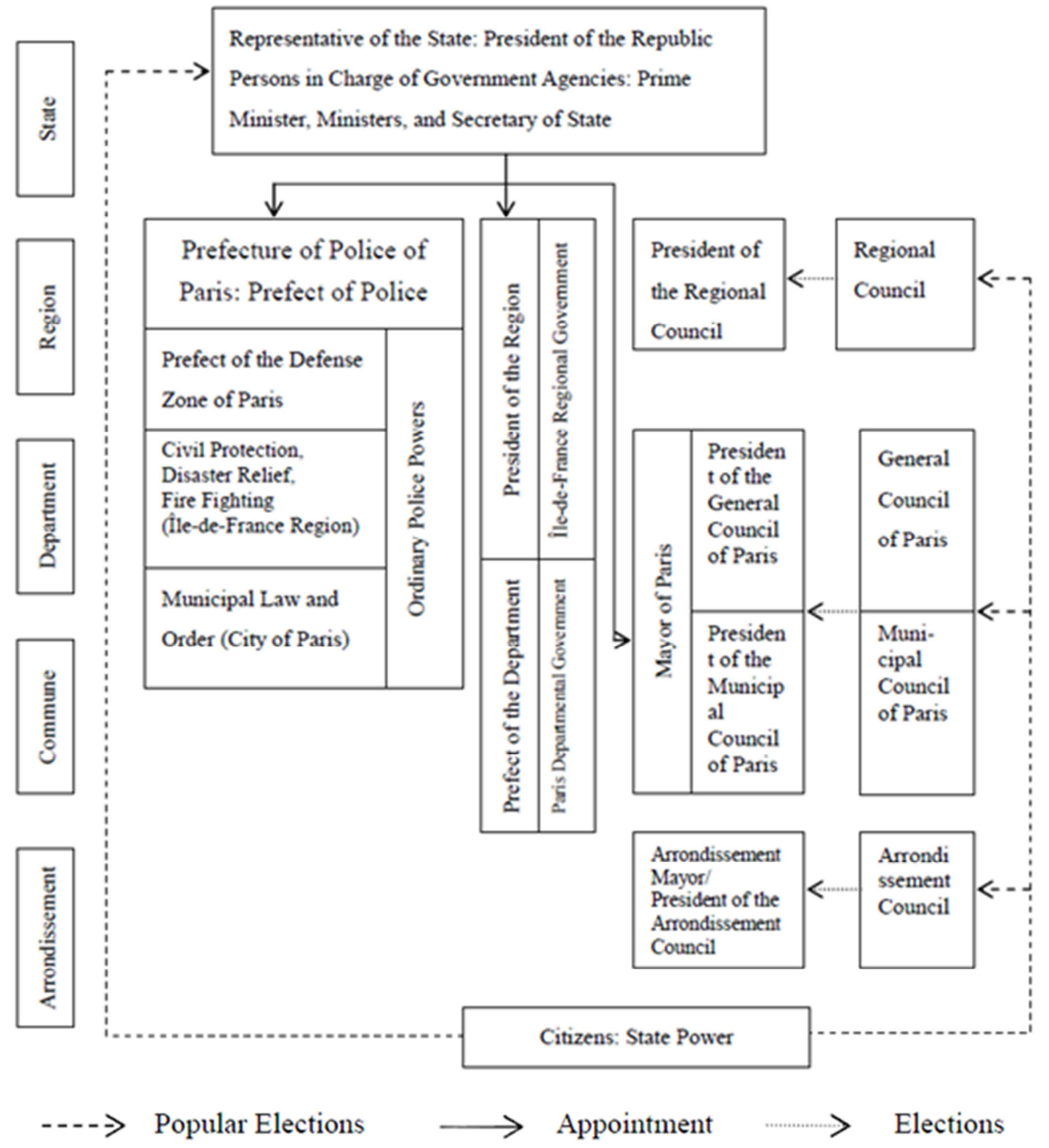

Source: adapted from Zhao (2007)

Figure 2. Governance Structure of Paris 


\section{Conclusion}

The development of local institutions in Paris reflects party competition and power struggles in French politics. The effects of the struggle between the French president and potential candidates in the next presidential election are clearly visible in the development of municipal politics in Paris. The administrative system for Paris is within the scope of central government planning, but is also influenced by the local political context. These facts combined with the individual relationships between local and national politicians, make central-local government relations vital in the reconciling of national and local interests. This could certainly not be inferred from strong executive power. Reforms to relevant laws and the subsequent operation of the system have shown that the reform of municipal government in Paris is the outcome of political competition. The original draft of François Mitterrand's PML law gave the twenty arrondissements in Paris completely independent executive and decision-making powers. However, the version that was finally passed made the arrondissements into something closer to an alliance of communes led by the city mayor. The socialist party hoped this would challenge the Gaullist influence in Paris, but in fact, it further strengthened the dominant position of the mayor, ensuring the maintenance of the centralist tradition in Parisian municipal politics. This phenomenon cannot be understood simply from the dimension of central-local government relations.

President Jacques Chirac has stated that the constitutional amendment in 2000 to reduce the presidential term to five years will lead France towards a "presidential system. French scholar Duhamel has also argued that since the "cohabitation" and "highly presidentialized semi-presidentialism" regime types represent the main failings of the Fifth Republic system, France should establish a "Sixth Republic" based on a parliamentary system. With regard to the major constitutional changes in 2008, the leadership of Nicolas Sarkozy produced a system that both strengthens the power of the president and parliament. This outcome might be closer to the meaning of semi-presidentialism (Hao, 2010). Historically, France has vacillated between choosing greater executive or greater legislative power. The choice between monarchical (presidential) or parliamentary power is still unfolding today. Faced with the current reduction in the power of the prime minister and the cabinet, and the increased powers of the parliament, what kind of power relations between president and parliament have emerged in France's semi-presidential system? Does the balancing of powers between president and parliament help the emergence of a presidential system? How does reform of the dual mandate system affect the logic of these systems? Aside from a discussion of the constitutional system, this study argues that it is necessary to bring together the dimensions of central-local government relations and the influence of major constitutional actors in local affairs to help us uncover the actual operations between executive and legislative power in France, and assess the content and direction of semi-presidentialism. Due to space limitations, in this paper, author have not explored other relevant factors, such as party politics or different local mechanisms. However, this paper hopes to provide a new research direction for the study of French semi-presidentialism and to speculate about future developments in France's constitutional system.

\section{References}

[1] Belkind, L. (2013, June 12). "The Negotiated Urbanism of Grand Paris Express," Metropolitics (France). Retrieved from http://www.metropolitiques.eu/The-Negotiated-Urbanism-ofGrand.html

[2] Brouard, S., Costa, O., Kerrouche, E., \& Schnatterer, T. (2013). Why do French MPs Focus More on Constituency Work than on Parliamentary Work? The Journal of Legislative Studies, 19(2), 141-159. doi: 10.1080/13572334.2013.787194.

[3] Brouard, S., Kerrouche, E., Deiss-Helbig, E., \& Costa, O. (2013). From Theory to Practice: Citizens' Attitudes about Representation in France. The Journal of Legislative Studies, 19(2), 178-195. doi: 10.1080/13572334.2013.787196.

[4] Chen, Chwen-wen (2004). The Financial Supervision of Local Governments in France. Journal of Social Sciences and Philosophy 16(1), 43-72.

[5] Costa, O. (2013a). Conclusion: Challenging the Conventional Wisdoms about Parliamentary Representation in France. The Journal of Legislative Studies, 19(2), 278-283. doi: 10.1080/13572334.2013.787202.

[6] Costa, O. (2013b). Introduction: Parliamentary Representation in France. The Journal of Legislative Studies, 19(2), 129-140. doi: 10.1080/13572334.2013.787193.

[7] Costa, O., Lefébure, P., Rozenbergm, O., Schnatterer, T., \& Kerrouche, E. (2012). Far Away, So Close: Parliament and Citizens in France. The Journal of Legislative Studies, 18(3-4), 294-313. doi: 10.1080/13572334.2012.706046.

[8] Duverger, M. (1970). Institutions Politiques et Droit Constitutionnel. (11th ed.). Paris, France: Presses Universitaires de France.

[9] Elgie, R. (2004). Semi-Presidentialism: Concepts, Consequences and Contesting Explanations. Political Studies Review, 2(3), 314-330. doi: 10.1111/j.1478-9299.2004.00012.x.

[10] Elgie, R. (2009). Duverger, Semi-presidentialism and the Supposed French Archetype. West European Politics, 32(2), 248-267. doi: 10.1080/01402380802670453.

[11] Elgie, R. (2011). Semi-Presidentialism: An Increasingly Common Constitutional Choice. In R. Elgie, S. Moestrup \& Y. $\mathrm{S} . \mathrm{Wu}$ (Eds.), Semi-Presidentialism and Democracy. Hampshire, England: Palgrave Macmillan.

[12] Elgie, R. \& Moestrup, S. (2007). Semi-presidentialism outside Europe: A Comparative Study. London, England: Routledge Press.

[13] Grossman, E. \& Sauger, N. (2009). Introduction: The Institutions of the French Republic at 50. West European Politics, 32(2), 243-247. doi: 10.1080/01402380802670438. 
[14] Hao, Pei-Chih. (2010). The Evolution of French Semi-Presidentialism: The Constitutional and Political Implications of the French Constitutional Amendment in 2008 Issues and Studies, 49 (2), 65-98.

[15] Hao, Pei-Chih. (2103). The Evolution of Semi-presidentialism: Presidentialization and Cabinet Instability. Issues and Studies, $52(1), 101-141$.

[16] Kuhlmann, S. (2007). Trajectories and Driving Factors of Local Government Reforms in Paris: A 'Deviant Case' of Institutional Development? Local Government Studies, 33(1), 5-24. doi: 10.1080/03003930601081002.

[17] Liu, Wen-shih (2007). The Evolution and Future Prospects of the Decentralization System in France. Soochow Journal of Political Science 30 (2), 85-91.

[18] Przeworski, A. \& Teune, H. J. (1970). Logic of Comparative Social Inquiry: Comparative Studies in Behavioral Science. New York: John Wiley \& Sons.

[19] Roper, S. D. (2002). Are All Semipresidential Regimes the Same? A Comparison of Premier- Presidential Regimes. Comparative Politics, 34(3), 253-272.

[20] Rowland, O. (May 2013). How many jobs should an MP have? Connexion (Monaco), Retrieved from $\mathrm{http}: / / \mathrm{www}$. connexionfrance.com/MPs-France-jobs-cumul-ma ndats-reforms-15159-news-article.html

[21] Shugart, M. \& Carey, J. M. (1992). Presidents and Assemblies: Constitutional Design and Electoral Dynamics. Cambridge, England: Cambridge University Press.
[22] Siaroff, A. (2003). Comparative Presidencies: the Inadequacy of the Presidential, Semi-Presidentialism and Parliamentary Distinction. European Journal of Political Research, 42(3), 287-312. doi: 10.1111/1475-6765.00084.

[23] Smith, A. \& Heywood, P. (2000). Regional Government in France \& Spain. London, England: Constitution Unit, University College London.

[24] Tiberj, V. \& Kerrouche, E. (2013). Up and Down, Old and New: Values and Value Systems of MPs and Voters in France," The Journal of Legislative Studies, 19(2), 160-177. doi: 10.1080/13572334.2013.787195.

[25] Weng, Y. C. (2013). Final Report of Resolving Disputes between Local Administration and Councils- France. Commissioned Research Report by Ministry of the Interior, Project NO. 102JCD02, Taipei, Taiwan: Ministry of the Interior.

[26] Wollmann, H. (2000). Local Government Systems: from Historic Divergence towards Convergence? Great Britain, France, and Germany as Comparative Cases in Point. Environment and Planning C: Government and Policy, 18(1), 33-55. doi: 10.1068/c9867.

[27] Wollmann, H. (2004). Local Government Reforms in Great Britain, Sweden, Germany and France: Between Multi-Function and Single-Purpose Organisations. Local Government Studies, 30(4), 639-665.

[28] Zhao, X. M. (2007). Current Politics in Paris: The Analysis of Administrative Systems, Master's dissertation, Shanghai, China: School of International Relations and Public Affairs, Fudan University. 